\title{
HUMIC HAPLUSTOX UNDER DIFFERENT LAND USES IN A HIGH ALTITUDE ENVIRONMENT IN THE AGRESTE REGION OF PERNAMBUCO, BRAZIL ${ }^{(1)}$
}

\author{
Jane Kelly Silva Araujo ${ }^{(2)}$, Mateus Rosas Ribeiroł ${ }^{(3)}$, Marcelo Metri Corrêa(4), Izabel \\ Cristina de Luna Galindo ${ }^{(5)}$ \& Valdomiro Severino de Souza Júnior ${ }^{(5)}$
}

\begin{abstract}
SUMMARY
The Garanhuns Plateau in the Agreste region of the State of Pernambuco, Brazil is characterized by humid climatic conditions due to orographic rains, unlike the surrounding semiarid region. These soils are subjected to intense agricultural use and are extremely important for the regional economy. This study was carried out in the municipality of Brejão in the Agreste region with the aim of assessing changes in humic Haplustox soils subjected to different land uses. Four plots with different vegetation covers (native forest, secondary shrubby vegetation (capoeira), traditional cropping system, and planted pasture) were selected, and samples were taken from a soil profile and four small pits surrounding it at each site. Physical and chemical properties were assessed, including aggregate stability, humic organic fractions, and a microbiological evaluation through determination of basal respiration, microbial biomass carbon, and metabolic quotient. The soils under study showed physical and chemical properties typical of a Haplustox, such as low nutrient content, low cation exchange capacity, and high levels of acidity and $\mathrm{Al}$ saturation. The total organic carbon (TOC) contents were high regardless of the type of land use. Aggregates $<2 \mathrm{~mm}$ were dominant in all the conditions under study. The TOC content was higher in the soil under capoeira, $43.91 \mathrm{~g} \mathrm{~kg}^{-1}$ on the surface, while 34.36 and $33.43 \mathrm{~g} \mathrm{~kg}^{-1}$ of TOC were observed in the first layer of forest and pasture soils, respectively. While the microbial biomass C (MBC) was greater than $700 \mathrm{mg} \mathrm{kg}^{-1}$ in the forest and pasture areas (in the 0-5 cm layer), and $588 \mathrm{mg} \mathrm{kg}^{-1}$ in the soil under capoeira, these numbers were not statistically different. In the cultivated soil area, there was a reduction of around $28 \%$ in TOC and MBC contents. Agricultural activity contributed to degradation of the humic
\end{abstract}

(1) Part of the Master Dissertation of the first author. Project funded by CNPq. Received for publication on September 19, 2013 and approved on May 5, 2014.

(2) Doctoral graduate student, Department of Agronomy - DA, Federal Rural University of Pernambuco - UFRPE. Av. Manoel de Medeiros, s/n, Dois Irmãos. CEP 52171-900, Recife (PE), Brazil. E-mail: janekaraujo@bol.com.br

(3) In memoriam, Associate Professor, DA/UFRPE.

(4) Full professor, DA/UFRPE. Campus Garanhuns. Av. Bom Pastor, s/n, Boa Vista. CEP 55296-901, Garanhuns (PE), Brazil. Email: marcelometri@yahoo.com

(5) Full Professor, DA, UFRPE. E-mail: galindo@depa.ufrpe.br, valdomiro@depa.ufrpe.br 
horizon, as can be seen from a significant decrease in the TOC and changes in the relative distribution of the humic fractions. In contrast, aggregate stability was not altered as a function of the different land uses; the soil under planted pasture and capoeira were similar to the soil under native forest. Humin was the most important humified fraction for $\mathrm{C}$ reserves, contributing over $40 \%$ of the TOC in these soils.

Index terms: land use, highland soils, humic substances, aggregate stability, microbial biomass $\mathbf{C}$.

\title{
RESUMO: LATOSSOLOS AMARELOS HÚMICOS SOB DIFERENTES TIPOS DE UTILIZAÇÃO EM UM AMBIENTE ALTIMONTANO NO AGRESTE DE PERNAMBUCO
}

\begin{abstract}
O Planalto de Garanhuns, no Agreste de Pernambuco, destaca-se por apresentar características climáticas privilegiadas, favorecidas pelas chuvas orográficas, distinguindose da região semiárida circundante. Essas áreas mais úmidas são conhecidas como "brejos de altitude" intensamente utilizadas e importantes para a economia regional. Este trabalho foi desenvolvido no município de Brejão, Agreste de Pernambuco, com o objetivo de identificar alterações nos atributos de Latossolos Amarelos Húmicos, submetidos às diferentes formas de uso do solo. Foram selecionados quatro tipos de utilização do solo (cultivo, capoeira, pastagem e vegetação nativa), sendo amostrados um perfil e quatro minitrincheiras em cada área. Foram avaliados atributos químicos e físicos, incluindo estabilidade dos agregados, composição da matéria orgânica humificada, além da avaliação microbiológica do solo, por meio da respiração basal, do carbono da biomassa microbiana e do quociente metabólico. Os solos estudados apresentaram características químicas e físicas típicas da classe dos Latossolos Amarelos, como baixa reserva de nutrientes, baixa capacidade de troca de cátions, acidez elevada e alta saturação por Al. Os teores de matéria orgânica do solo foram altos, independentemente do tipo de utilização. O teor de carbono orgânico total (COT) foi maior no solo sob capoeira, 43,91 $\mathrm{g} \mathrm{kg}^{-1}$, superficialmente, enquanto 34,36 e $33,43 \mathrm{~g} \mathrm{~kg}^{-1}$ foram constatados nos solos sob floresta e pastagem, respectivamente. O teor de carbono microbiano (CBM) foi superior a $700 \mathrm{mg} \mathrm{kg}^{-1}$ nas áreas sob floresta e pastagem, na camada de $0-5 \mathrm{~cm}$, e $588 \mathrm{mg} \mathrm{kg}^{-1}$ no solo sob capoeira; no entanto, não diferiram estatisticamente. Na área cultivada houve redução em torno de $28 \%$ no teor de COT e CBM. Os agregados $>2 \mathrm{~mm}$ predominaram em todas as áreas. A atividade agrícola contribuiu para a degradação do horizonte húmico, evidenciada pela significativa perda de COTe alteração da distribuição relativa das frações humificadas. Já a estabilidade dos agregados não sofreu alterações em razão dos diversos tipos de uso do solo. Os solos sob pastagem e a capoeira foram semelhantes ao solo sob vegetação nativa. A humina representou a fração humificada mais importante para a reserva de $C$, contribuindo com mais de $40 \%$ do COT nesses solos.
\end{abstract}

Termos de indexação: uso do solo, solos de altitude, substâncias húmicas, estabilidade de agregados, $C$ microbiano.

\section{INTRODUCTION}

The humic horizon is a mineral surface horizon characterized by a dark color (value and chroma $\leq 4$ ), reflecting the significant content of organic carbon (OC) distributed at that depth (Embrapa, 2013). The humic A horizon is overdeveloped and rich in organic matter $(\mathrm{OM})$ when it occurs in Oxisols (> $100 \mathrm{~cm})$.

The genesis of humic horizons in Oxisols and their great capacity for storage of soil $\mathrm{C}$ is not well understood. According to Lepsch \& Buol (1986), these soils are paleosols that formed under conditions favorable to the accumulation of $\mathrm{OM}$ at that depth in the past, and this is preserved in some surviving stable surfaces and landscapes. The stability of OM in these soils has been related mainly to cold climates, acidity, and high $\mathrm{Al}$ saturation, as well as the association of $\mathrm{OM}$ with the mineral fraction of the soil, especially poorly crystalline forms of $\mathrm{Al}$ (Queiroz Neto \& Castro, 1974; Lepsch \& Buol, 1986; Ker, 1997; Marques et al., 2011).

Oxisols with a humic A horizon (Lh) are commonly found in good condition in stable and old geomorphic surfaces and are associated with mild climate highland environments in southeastern and southern Brazil (Ker, 1997). In northeastern Brazil, these soils occur in small areas under ecological tension (enclaves or ecotones) between dense ombrophilous forests and 
the seasonal semi-deciduous forest and caatinga (xeric shrubland), and are commonly located at the top of a watershed/hillside (Brazil, 1972).

In areas in the northeastern region of Brazil with altitudes ranging from 150 to $1,200 \mathrm{~m}$, such as the Garanhuns Plateau, orographic rainfall ensures levels of rainfall greater than $1,000 \mathrm{~mm} \mathrm{yr}^{-1}$ (Araújo Filho et al., 2000; Velloso et al., 2002) and causes the emergence of rainforests. These caatinga moist forest enclaves are a disjunction of the Atlantic Forest and are considered "small islands of forests on isolated massifs" and locally named, "Brejos de Altitude" (highland swamps).

The Garanhuns Plateau in the Agreste region of Pernambuco is known for its vast size (Andrade-Lima, 1966), and it is important to the local economy because of milder conditions amid the drylands of the semiarid Northeast (Tabarelli et al., 2004). Furthermore, a large portion of the cultivated areas are sustained by humic Oxisols, which are characterized by great friability, permeability, and OM content (Ker, 1997).

The general pattern of land use in the Garanhuns Plateau is predominately pasture, bean, and cassava cropping on small farms, and coffee cropping in some medium-sized areas (Araújo Filho et al., 2000; Galvão, 2007; Carvalho \& Souza, 2008).

The influence of land use systems on the contents and quality of organic matter of the Lh and, consequently, on the properties and the ability of the soil to promote $\mathrm{C}$ stabilization (sequestration) is a research subject of great interest. Moreover, studies on the effects of different land uses on the properties of the Lh are scarce in the literature and mostly refer to the South and Southeast areas of Brazil (Silva, 1997; Silva \& Vidal Torrado, 1999; Marques et al., 2011; Assis et al., 2012).

The aim of this study was to identify possible changes in the physical and chemical properties, as well as the OM, of the Lh subjected to the main systems of land use in caatinga moist forest enclaves in the State of Pernambuco, Brazil.

\section{MATERIALS AND METHODS}

\section{Overview of study areas}

The area under study is located within the municipality of Brejão in the Agreste region of Pernambuco (09. 01' 49' S and $36^{\circ} 34^{\prime} 07^{\prime \prime} \mathrm{W}$ ) on the Garanhuns Plateau. According to the Köppen classification, the climate is Csa, a mesothermal climate with dry and hot continental summers. The rainy season begins in January/February and ends in September or possibly October. The average annual rainfall and temperature are $1,404 \mathrm{~mm}$ and $22.3^{\circ} \mathrm{C}$, respectively, and the average temperature in the coldest month is $16.8{ }^{\circ} \mathrm{C}$ (Lamepe/Itep, 2010). The vegetation in the sampling areas is subperennial forest characterized as secondary vegetation (Melo \& Rodal, 2003). The soils of the sampled areas were classified according to the SiBCS (Embrapa, 2013) as a "Latossolo Amarelo distrocoeso húmico" with clayey texture, formed from tertiary sediments over crystalline rocks (Embrapa, 2000). The particle size properties of all the soils studied are shown in table 1.

\section{Selection of areas and sampling}

Four areas were selected for this study: a conservation area with native subperennial forest, considered a benchmark for assessing the original conditions of the soil; an area cultivated with subsistence crops (maize, beans, and cassava) for 35 years that was in the fallow period during the soil sampling; a secondary shrubby vegetation area (capoeira) that had been subject to sporadic slash-andburn techniques for 10 years; and a Brachiaria (signal grass) pasture area of 30 years with sparse cashew trees. The sampled areas are situated on the top of the plateau with flat and softly sloping terrain at an altitude of $850 \mathrm{~m}$. All sampled areas have similar topography, altitude, and soil conditions.

A soil profile and four 60-cm-deep pits located $10 \mathrm{~m}$ away from the profile were made, from which samples were taken in each area. Disturbed soil samples were collected from the soil profiles and small pits in the first three horizons (A1, A2, and A3) for physical and chemical analysis, and undisturbed soil samples were taken with a soil sample ring for determining bulk density.

Undisturbed soil samples were also collected at the 0-15 and $15-35 \mathrm{~cm}$ depths to evaluate aggregate

Table 1. Particle size properties of soils under different uses

\begin{tabular}{lccc}
\hline Depth & Sand & Silt & Clay \\
\hline \multirow{2}{*}{$\mathrm{cm}$} & \multicolumn{3}{c}{ g kg-1 } \\
\cline { 2 - 4 } $0-15$ & 693 & Forest \\
$15-35$ & 690 & 26 & 281 \\
$35-67$ & 635 & 33 & 291 \\
& \multicolumn{3}{c}{ Traditional cropping system } \\
$0-15$ & 727 & 34 & 239 \\
$15-35$ & 660 & 33 & 307 \\
$35-67$ & 542 & 40 & 418 \\
& & Capoeira & \\
$0-15$ & 659 & 49 & 292 \\
$15-35$ & 569 & 47 & 384 \\
$35-65$ & 550 & 48 & 402 \\
& & & \\
$0-15$ & 688 & 20 & 292 \\
$15-36$ & 600 & 30 & 370 \\
$35-65$ & 467 & 40 & 493 \\
\hline
\end{tabular}


stability. Soils were sampled at the 0-5 and 5-10 cm depths for microbiological analyses, and these samples were maintained under refrigeration. Subsequently, the disturbed samples were air dried and passed through a $2-\mathrm{mm}$ mesh sieve to obtain air-dried fine earth (ADFE).

\section{Physical and chemical analyses}

The following physical and chemical properties of soils were determined according to Embrapa (1997): bulk density (BD), evaluated by the volumetric ring method $\left(100 \mathrm{~cm}^{3}\right) ; \mathrm{pH}$ in water and $1 \mathrm{~mol} \mathrm{~L}^{-1} \mathrm{KCl}$ (soil:liquid ratio of 1:2.5); exchangeable $\mathrm{Ca}^{2+}, \mathrm{Mg}^{2+}$, and $\mathrm{Al}^{3+}$ extracted by $1 \mathrm{~mol} \mathrm{~L}^{-1} \mathrm{KCl}$; and available $\mathrm{K}^{+}$, $\mathrm{Na}^{+}$, and $\mathrm{P}$ extracted by Mehlich- 1 and $\mathrm{H}+\mathrm{Al}$ by $1 \mathrm{~mol} \mathrm{~L}^{-1}$ calcium acetate at $\mathrm{pH}$ 7.0. The sum of bases (SB), cation-exchange capacity (CEC), base saturation $(\mathrm{V})$, and $\mathrm{Al}$ saturation $(\mathrm{m})$ were calculated. The TOC was determined according to the method of Yeomans \& Bremner (1988), and the total nitrogen (TN) was determined according to Mendonça \& Matos (2005).

\section{Distribution of aggregates}

The air-dried aggregates which passed through an $8 \mathrm{~mm}$ mesh sieve and were retained on a $4-\mathrm{mm}$-mesh sieve were analyzed. Dry aggregate size distribution was assessed through dry sieving, according to Kemper \& Rosenau (1986) using $50 \mathrm{~g}$ samples of soil in a Produtest oscillating sieve shaker (graduation 5, for $10 \mathrm{~min}$ ) on a nest of sieves with $3.35,1.7,0.85,0.6$, $0.425,0.3,0.212,0.15,0.106,0.075$ and $0.053 \mathrm{~mm}$ meshes. The aggregate classes were quantified through weighing.

The wet sieving method of Kemper \& Chepil (1965) was used to assess aggregate stability. Samples of 100 $\mathrm{g}$ of soil were pre-wetted slowly. Subsequently, the samples were immersed in water in a Yoder vertical oscillation device with a nest of sieves with $2,1,0.5$, and $0.25 \mathrm{~mm}$ meshes at a frequency of 30 oscillations per minute for $15 \mathrm{~min}$. Then, the fractions retained on each sieve were dried at $105^{\circ} \mathrm{C}$ for $24 \mathrm{~h}$ prior to weighing. The mean weight diameter (MWD) and the geometric mean diameter (GMD) were calculated as in Kemper \& Chepil (1965) by the following formula:

$$
\mathrm{MWD}=\sum_{\mathrm{i}=1}^{\mathrm{n}} \mathrm{x}_{\mathrm{i}} \mathrm{w}_{\mathrm{i}}, \text { and GMD }=10^{\sum_{\mathrm{i}=1}^{\mathrm{n}} \mathrm{x}_{\mathrm{i}} \operatorname{logw}_{\mathrm{i}}}
$$

where $\mathrm{x}_{\mathrm{i}}=$ class center diameter $(\mathrm{mm})$ and $\mathrm{w}_{\mathrm{i}}=$ the weight of aggregates within each class and the aggregates total mass ratio.

A sensitivity index (SI) was calculated according to Bolinder et al. (1999):

$$
\mathrm{SI}=\mathrm{MWD}_{\mathrm{t}} / \mathrm{MWD}_{\mathrm{o}}
$$

where $\mathrm{MWD}_{\mathrm{t}}=\mathrm{MWD}$ of the soil tested, and $\mathrm{MWD}_{\mathrm{o}}=$ MWD of the soil under the original vegetation cover.

\section{Chemical fractionation of organic matter}

Quantitative chemical fractionation of humic substances was performed based on solubility in acid and alkali media using $1.0 \mathrm{~g}$ ADFE and $0.1 \mathrm{~mol} \mathrm{~L}^{-1}$ $\mathrm{NaOH}$ in the soil/extractant at a ratio of 1:20 w/v, separating the following fractions (Mendonça \& Matos, 2005): fulvic acids (FA), humic acids (HA), and humins $(\mathrm{H})$, with subsequent determination of TOC in every fraction according to the method of Yeomans \& Bremner (1988). Humified C was obtained from the sum of the $\mathrm{C}$ content from the three humic fractions.

\section{Soil basal respiration (BR), microbial biomass $\mathrm{C}(\mathrm{MBC})$ and metabolic quotient $\left(q \mathrm{CO}_{2}\right)$}

To determine the BR, $50 \mathrm{~g}$ of soil was hermetically incubated in the presence of $0.5 \mathrm{~mol} \mathrm{~L}^{-1} \mathrm{NaOH}$ for $72 \mathrm{~h}$ according to Mendonça \& Matos (2005). Control flasks containing no soil sample were maintained. The MBC was determined by the irradiation-extraction method using $0.5 \mathrm{~mol} \mathrm{~L}^{-1} \mathrm{~K}_{2} \mathrm{SO}_{4}$ as the extractant. Irradiation of $20 \mathrm{~g}$ of soil was carried out using a domestic microwave oven $(658 \mathrm{~W})$ and an equal amount of soil was not subjected to irradiation (Mendonça \& Matos, 2005). The $\mathrm{C}$ content was determined in the extracts from the irradiated and non-irradiated samples using the colorimetric method (Bartlett \& Ross, 1988). The $q \mathrm{CO}_{2}$ was obtained from the BR per MBC unit ratio (Silva et al., 2007).

\section{Statistical analyses}

The changes in soil properties were studied using a $4 \times 3 \times 5$ randomized factorial design, corresponding to a reference area and three land uses, three depths, and five replications, according to Silva \& Silva (1982). In cases where significant values were detected in the F-test, the comparison of means was performed by Tukey's test (both $\mathrm{p}<0.05$ ) using the SAS Institute (9.1) software (SAS, 2006).

\section{RESULTS AND DISCUSSION}

Alterations in chemical properties (Table 2) as a function of land use were more evident in the first $15 \mathrm{~cm}$ due to the use of low technology management systems, resulting in the disturbance of only a small layer of soil.

A strong acidic reaction was observed in all areas, with $\mathrm{pH}$ values in water higher than those observed in $\mathrm{KCl}$, indicating a predominance of negative charges on the exchange complex. The $\mathrm{pH}$ values were below 5 in the forest, cultivated, and capoeira soils. The acidity of these soils was expected considering the preweathered parent materials, poor base content, and the amphoteric nature of aluminum in these soils. Furthermore, OM decomposition also contributed to 
Table 2. Physical and chemical properties of soils under different uses

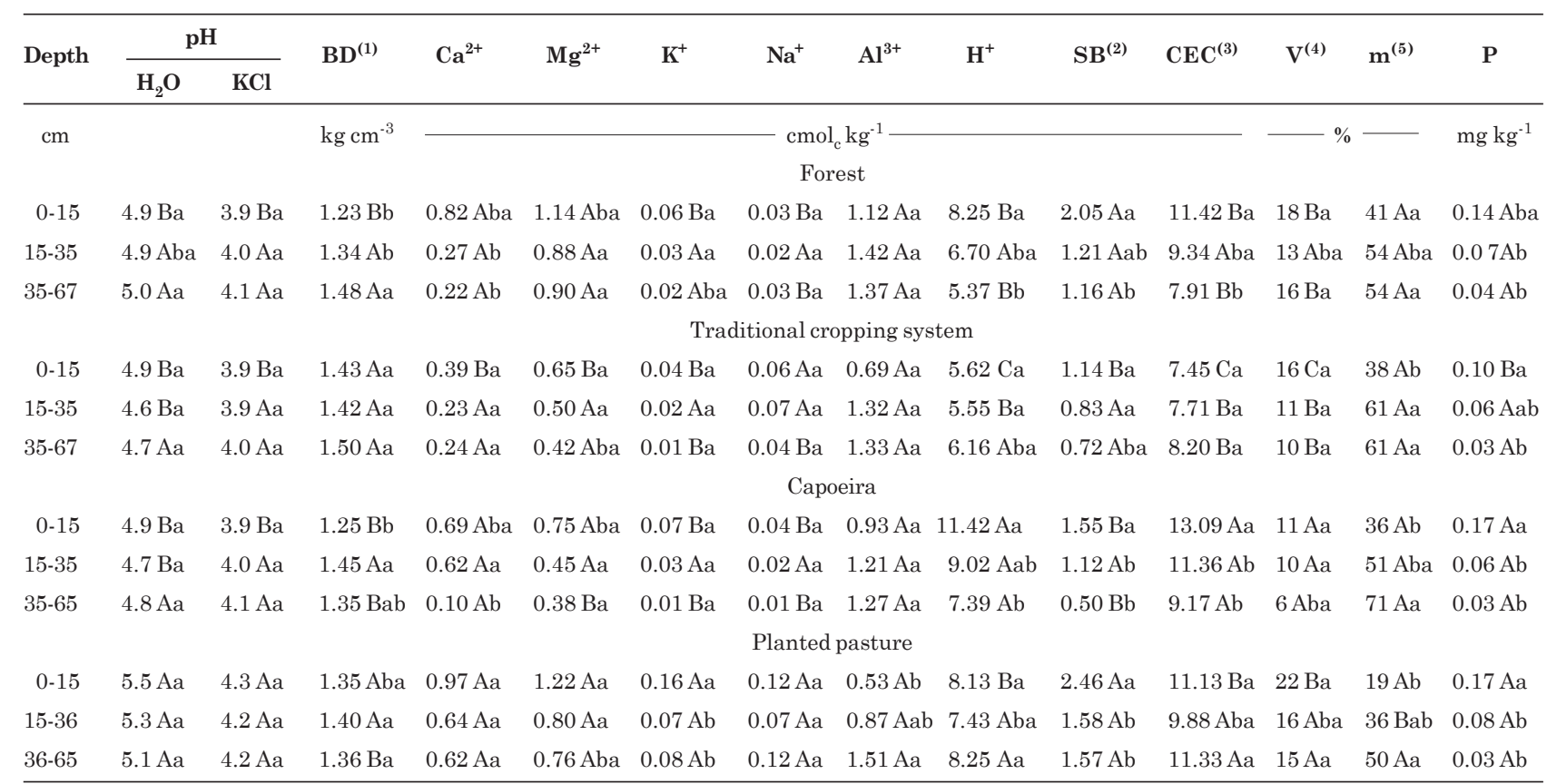

(1) BD: bulk density; ${ }^{(2)} \mathrm{SB}$ : sum of bases; ${ }^{(3)} \mathrm{CEC}$ : Cation-exchange capacity; ${ }^{(4)} \mathrm{V}$ : base saturation; ${ }^{(5)} \mathrm{m}$ : aluminum saturation. Uppercase letters compare types of management at the same depth. Lowercase letters compare depths within the same type of management. Mean values followed by the same letter do not differ by Tukey's test at $5 \%$.

soil acidification by the release of $\mathrm{H}^{+}$(Guppy et al., 2005), which was observed in the surface layers.

The $\mathrm{pH}$ increased significantly in the pasture soil, ranging from 5.5 to 5.3 on the surface, which led to a decrease in $\mathrm{Al}^{3+}$ availability and lower $\mathrm{Al}$ saturation in this area. This increase in $\mathrm{pH}$ in water in the pasture soil may be associated with the increase in the content of low molecular weight organic compounds in the soil (acetic acid, malic acid, citric acid, etc.), as suggested by the lower humification of organic matter in this area, which stimulates $\mathrm{H}^{+}$adsorption, therefore raising the $\mathrm{pH}$ in water (Hue \& Licudine, 1999). Similar results were reported by Rukshana et al. (2011), who demonstrated that the addition of organic compounds caused soil $\mathrm{pH}$ to increase due to $\mathrm{H}^{+}$consumption. However, this study also found that the $\mathrm{pH}$ may decrease or remain unaffected, depending on the chemical functional group, rate of addition, decomposition, and the initial soil $\mathrm{pH}$. The increase in $\mathrm{pH}$ in the pasture soil was also previously attributed to animal excreta (Haynes \&Williams, 1992; Shand $\&$ Coutts, 2006; Brunetto et al., 2012).

Aluminum saturation (m) shows values above $50 \%$ in most layers studied in all of the areas. This saturation was significantly lower at the surface, coinciding with the high levels of OM. Previous research has shown that the effects of the organic compounds of low molecular weight from plant residues and manures in reducing aluminum concentrations in soil solution are attributable to both an increase in $\mathrm{pH}$ and the complexing ability of $\mathrm{OM}$ for Al (Miyazawa et al., 1993; Naramabuye \& Haynes, 2006; Nolla \& Anghinoni, 2006).

The concentration of exchangeable $\mathrm{Ca}^{2+}, \mathrm{Mg}^{2+}$, and $\mathrm{K}^{+}$were extremely low in all the areas studied due to parent materials. The $\mathrm{Ca}$ and $\mathrm{Mg}$ concentrations were reduced significantly in the cultivated soil compared with the other areas due to the combined action of removal of nutrients by crops and the adoption of management practices that do not favor the input of soil C. The sharp nutrient decrease, along with C levels, in the cultivated soil and with depth in all the soils indicates the important role of surface OM in nutrient cycling and sustainability of these environments (Table 2 ). The concentration of these elements in pasture and capoeira soils was not different from the control. This may be explained by the high levels of OM observed in these areas. In the pasture soil, an increase of macronutrients is expected because approximately 60 to $95 \%$ of ingested nutrients can return, due to grazing excretions (Haynes \& Williams, 1993; Ceretta et al., 2003). The increase in macronutrients may also be due to the migration of ions (those linked to water-soluble organic substances), such as those originating from root senescence (Miyazawa et al., 1993). The exchangeable $\mathrm{K}$ content was highest in soil pasture, in part, due to the low levels found in other areas.

The highest CEC values were found in the soil under capoeira in the surface layer $\left(13.09 \mathrm{cmol}_{\mathrm{c}} \mathrm{kg}^{-1}\right)$, and the cultivated soil had the lowest CEC value $\left(7.45 \mathrm{cmol}_{\mathrm{c}} \mathrm{kg}^{-1}\right)$, while pasture and forest soils did not differ. The $\mathrm{H}^{+}$ions occupied $87 \%$ of the exchange sites in the soil under capoeira, while, in other soils, 
such occupancy was approximately $70 \%$. The higher $\mathrm{CEC}$, and $\mathrm{H}+\mathrm{Al}$ in organic-matter-rich surface horizons indicate that most negative charges are due to organic compounds.

Base saturation $(\mathrm{V})$ distinguished environments in the first $15 \mathrm{~cm}$; the pasture soil tended to be more saturated, the forest soil showed the highest values $(>18 \%)$, differing from the cultivated soil (16\%), and the lowest value was observed in the capoeira soil (11\%).

Available $\mathrm{P}$ was related to $\mathrm{OM}$, both with respect to its function as a source and its performance in reducing fixation, because of the release of organic acids in the soil that compete with adsorption sites and decrease phosphate fixation (Andrade et al., 2003). In the cultivated soil, the available $\mathrm{P}$ content in the first layer was lower than in the other areas under study, which is in accordance with decreasing levels of OM.

The highest TOC content was observed in soil under secondary forest ( $43.91 \mathrm{~g} \mathrm{~kg}^{-1}$ in the first layer), differing from the other areas studied, while the cultivated soil had a lower content of TOC $\left(24.60 \mathrm{~g} \mathrm{~kg}^{-1}\right.$ on the surface). The soils under forest and pasture were not different from each other (34.36 and $33.43 \mathrm{~g} \mathrm{~kg}^{-1}$, respectively) in the surface layer. These results indicate high $\mathrm{OM}$ accumulation and a $\mathrm{C}$ sink, even in the subsoil and despite the decrease in TOC content with depth in all the soils (Table 3).

Table 3. Total organic carbon (TOC), total nitrogen (TN) and $\mathrm{C} / \mathrm{N}$ ratio of soils under different uses

\begin{tabular}{cccc}
\hline Depth & TOC & TN & C/N \\
\hline \multirow{2}{*}{ cm } & \multicolumn{3}{c}{ g kg $^{-1}$} \\
\cline { 2 - 3 } $0-15$ & $34.36 \mathrm{Ba}$ & $2.49 \mathrm{Aa}$ & $14 \mathrm{Aa}$ \\
$15-35$ & $24.19 \mathrm{Ab}$ & $1.62 \mathrm{Ab}$ & $15 \mathrm{Aa}$ \\
$35-67$ & $17.98 \mathrm{Ab}$ & $0.93 \mathrm{Ac}$ & $20 \mathrm{Ba}$ \\
& \multicolumn{2}{c}{ Traditional cropping system } \\
$0-15$ & $24.60 \mathrm{Ca}$ & $1.54 \mathrm{Ba}$ & $16 \mathrm{Ab}$ \\
$15-35$ & $22.16 \mathrm{Aa}$ & $1.26 \mathrm{Aa}$ & $18 \mathrm{Ab}$ \\
$35-67$ & $17.60 \mathrm{Aa}$ & $0.59 \mathrm{Ab}$ & $28 \mathrm{Aa}$ \\
& \multicolumn{4}{c}{ Capoeira } \\
$0-15$ & $43.91 \mathrm{Aa}$ & $2.55 \mathrm{Aa}$ & $17 \mathrm{Aa}$ \\
$15-35$ & $25.91 \mathrm{Ab}$ & $1.27 \mathrm{Ab}$ & $21 \mathrm{Aa}$ \\
$35-65$ & $20.80 \mathrm{Ab}$ & $1.00 \mathrm{Ab}$ & $22 \mathrm{Ba}$ \\
& & Planted pasture \\
$0-15$ & $33.43 \mathrm{Ba}$ & $2.37 \mathrm{Aa}$ & $15 \mathrm{Aa}$ \\
$15-36$ & $25.69 \mathrm{Aab}$ & $1.64 \mathrm{Ab}$ & $16 \mathrm{Aa}$ \\
$35-65$ & $20.66 \mathrm{Ab}$ & $0.99 \mathrm{Ac}$ & $21 \mathrm{Ba}$ \\
\hline
\end{tabular}

Uppercase letters compare types of management at the same depth. Lowercase letters compare depths within the same type of management. Mean values followed by the same letter do not differ by Tukey's test at $5 \%$.
The higher TOC content in the soil under capoeira is due to the high input of organic matter. This is compatible with the dynamics of soil nutrients according to Odum (1985), where the transfer and partial decomposition of litter initially promotes the accumulation of $\mathrm{OM}$ on the soil surface because the inputs are higher than the decomposition. At a second stage, the decomposition rates are similar to deposition rates, promoting a state of balance between accumulation and deposition of litter, similar to the situation that occurs in the control area (forest). In the pasture soil, the root systems of high-yield and short-cycle grasses, combined with the contribution of animals in returning nutrients and OM through droppings, may explain the accumulation of OC in this area. According to Marin-Spiotta et al. (2008), C losses in pastures may be minimal or there may even be a small OM gain compared with natural ecosystems.

The average reduction in TOC content in the cultivated soil was $28 \%$ relative to the reference sample, reflecting the soil preparation practices that favor OM decomposition, in addition to the small contribution of crops residues during cultivation. According to Mielniczuk et al. (2003), in areas where conservation practices are not adopted, losses of up to $50 \%$ of the original $\mathrm{C}$ content in less than 10 years of cultivation have been verified. It is quite common to observe the effective decrease of $\mathrm{OC}$ content induced by conventional farming systems (Gol, 2009; Don et al., 2011, Vaccari et al., 2012).

The TN content of the soil indicates a close relationship with the TOC because most $\mathrm{N}$ is found in organic compounds (Camargo et al., 1999a). The $\mathrm{C} / \mathrm{N}$ ratio reflected the predominance of humified $\mathrm{OM}$ in all areas and at all depths.

The BD values were high in all areas (Table 2) at the $35 \mathrm{~cm}$ depth because of the cohesive characteristics of the soil. The cultivated and pasture soils showed increased density in the surface layer $(0-15 \mathrm{~cm})$, indicating that the land use system contributed to compaction of the surface horizon.

\section{Distribution of aggregates}

The low disintegration of aggregates, especially during wet sieving, reflects high stability. This was indicated by the predominance of aggregates $>2.0$ $\mathrm{mm}$ in all soils, demonstrating the good physical condition of the soil. Water-stable aggregates contribute to improved porosity, increased water infiltration and erosion resistance.

In general, there were no significant changes in the distribution of aggregate classes depending on soil use or depth (Tables 4 and 5). This result may be related to the relatively high organic $\mathrm{C}$ concentration in all the soils studied, regardless of land use type. Pinheiro et al. (2004) also observed that there was no significant difference among soil aggregates $2.0 \mathrm{~mm}$ 
Table 4. Distribution of aggregate size classes and aggregation indices determined by wet sieving in different depths of soils under different uses

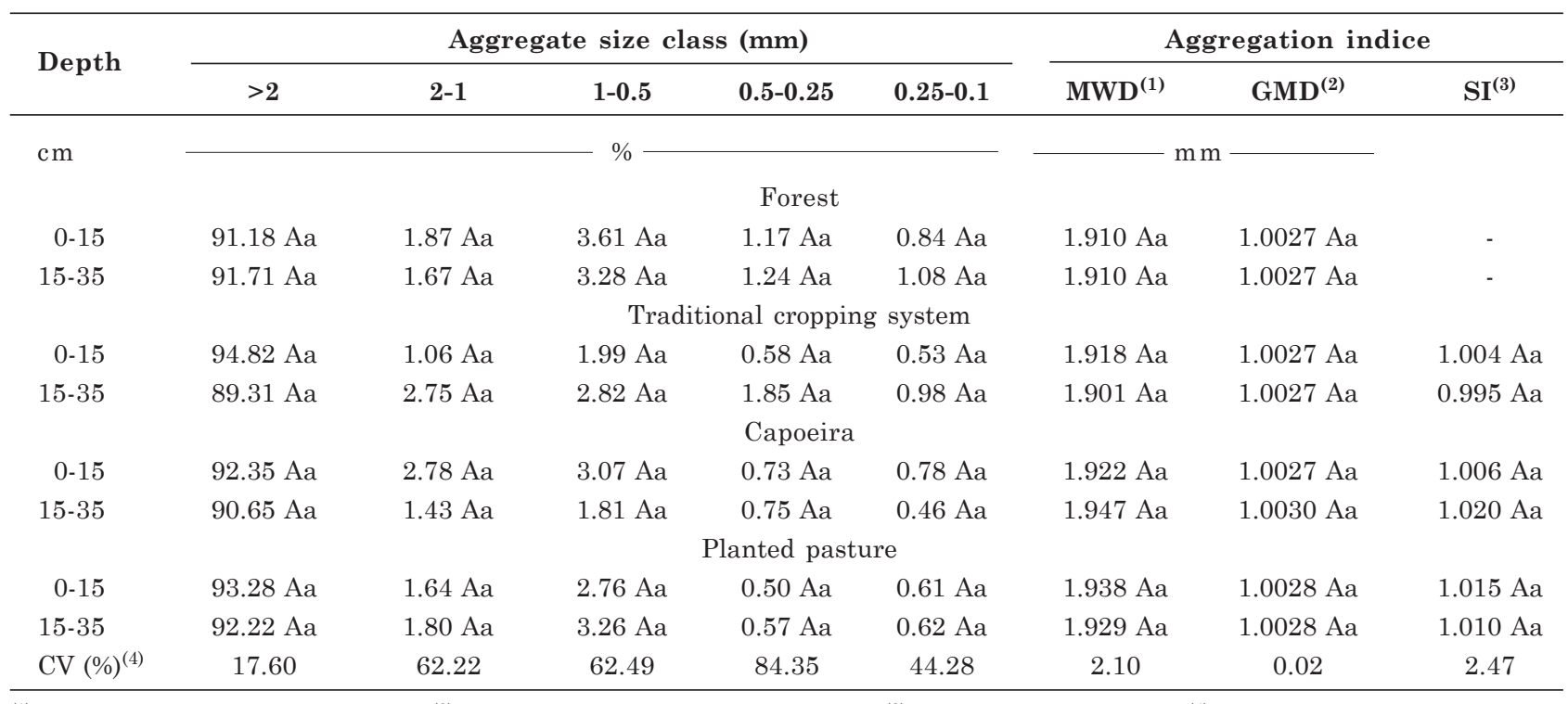

(1) MWD: mean weight diameter; (2) GMD: geometric mean diameter; ${ }^{(3)}$ SI: sensitivity index; (4) CV: coefficient of variation. Uppercase letters compare types of management at the same depth. Lowercase letters compare depths within the same type of management. Mean values followed by the same letter do not differ by Tukey's test at $5 \%$.

from conventional tillage, contour tillage with animal traction, and bare soil in Oxisols in the mountainous region of Rio de Janeiro, except for the 0-5 cm layer, indicating the influence of OM. Part of the aggregate size variation and, therefore, the aggregation indices in tropical soils can be attributed to variations in $\mathrm{OM}$ (Castro Filho, 1988).

Additionally, the aggregates $>3.35 \mathrm{~mm}$ determined by dry sieving were significantly less common in the $15-35 \mathrm{~cm}$ layer in all areas. The exception to this result was the capoeira soil, in which the aggregates $>3.35$ $\mathrm{mm}$ were more abundant in the $15-35 \mathrm{~cm}$ layer, consistent with the significant reduction in aggregates with a size from 1.7 to $0.85 \mathrm{~mm}$ in the same layer. These results indicate that the fraction of aggregates with a size from 1.7 to $0.85 \mathrm{~mm}$ may be more sensitive to changes in soil management.

The aggregation indices MWD and GMD were not altered as a function of land use. The MWD is an estimate of the relative amount of soil in each class of aggregates and increases with a higher percentage of large aggregates. The GMD is an estimate of the aggregate size class of highest incidence (Castro Filho et al., 2002).

The MWD of water-stable aggregates was 1.92 $\mathrm{mm}$ on average, while the aggregates determined by the dry route showed an average MWD of $2.43 \mathrm{~mm}$. The increase in MWD resulted mainly from the increase of approximately $400 \%$ in the $2-1 \mathrm{~mm}$ aggregate class when subjected to dry sieving, showing that this class has higher resistance to mechanical action rather than to hydric action. This result also reflects the cohesive characteristics of the soil, which provides resistant aggregates when dry and provides friable aggregates when moist. In contrast, the dominant aggregate class did not change as a function of the analytical method, with an average MWD of $1.0 \mathrm{~mm}$.

The sensitivity index (SI) assesses the influence of different types of vegetation and management on aggregate stability. The higher the SI value, the more similar the soil is to its natural condition (Bolinder et al., 1999). The SI values of all the soils studied were similar, confirming their high aggregate stability.

It is known that in acidic tropical soils (1:1 clays), $\mathrm{Fe}$ and $\mathrm{Al}$ oxyhydroxides are the main aggregate stabilizers (Six et al., 2002). Therefore, OM has a secondary role in aggregate formation and stabilization. However, the results of this study in the humic horizons indicate that OM may play a key role in aggregate stability. Despite reduction in OC content with increasing land use, it remained high in all the systems, contributing to soil aggregation. According to Azevedo \& Bonumá (2004), linkages formed by organo-mineral complexes seem to be stronger than the electrostatic attractions that occur between the oxides and clays.

\section{Chemical fractionation of organic matter}

The amount of $\mathrm{C}$ stored in the form of humus (humified-C) corresponded to values above $70 \%$ in the forest soil in all layers evaluated (Table 6) and are consistent with the values suggested as typical by Stevenson (1994). 
Table 5. Distribution of aggregate size classes determined by dry sieving in different depths of soils under different uses

\begin{tabular}{|c|c|c|c|c|c|c|c|c|}
\hline \multirow{2}{*}{ Depth } & \multicolumn{8}{|c|}{ Aggregate size class (mm) } \\
\hline & $>3.35$ & $3.35-1.7$ & $1.7-0.85$ & $0.85-0.6$ & $0.6-0.425$ & $0.425-0.3$ & $0.3-212$ & $0.212-0.15$ \\
\hline \multicolumn{9}{|l|}{$\mathrm{cm}$} \\
\hline & \multicolumn{8}{|c|}{ Forest } \\
\hline $0-15$ & $59.29 \mathrm{Aa}$ & $24.11 \mathrm{Aa}$ & $8.61 \mathrm{~A} \mathrm{a}$ & $4.67 \mathrm{Aa}$ & $3.34 \mathrm{Aa}$ & $2.67 \mathrm{Aa}$ & $2.42 \mathrm{Aa}$ & $1.88 \mathrm{Aa}$ \\
\hline \multirow[t]{2}{*}{$15-35$} & $48.75 \mathrm{ABa}$ & $28.85 \mathrm{Aa}$ & $12.75 \mathrm{Aa}$ & $5.67 \mathrm{Aa}$ & $4.87 \mathrm{Aa}$ & $3.79 \mathrm{Aa}$ & $2.83 \mathrm{Aa}$ & $2.25 \mathrm{Aa}$ \\
\hline & \multicolumn{8}{|c|}{ Traditional cropping system } \\
\hline $0-15$ & $51.35 \mathrm{Aa}$ & $28.86 \mathrm{Aa}$ & $8.98 \mathrm{Aa}$ & $6.08 \mathrm{Aa}$ & $5.38 \mathrm{Aa}$ & $4.00 \mathrm{Aa}$ & $2.98 \mathrm{Aa}$ & $2.16 \mathrm{Aa}$ \\
\hline \multirow[t]{2}{*}{$15-35$} & $46.78 \mathrm{Ba}$ & $36.85 \mathrm{Aa}$ & $9.43 \mathrm{ABa}$ & $3.95 \mathrm{Aa}$ & $3.09 \mathrm{Aa}$ & $3.05 \mathrm{Aa}$ & $2.20 \mathrm{Aa}$ & $1.99 \mathrm{Aa}$ \\
\hline & \multicolumn{8}{|c|}{ Capoeira } \\
\hline $0-15$ & $56.29 \mathrm{Aa}$ & $32.89 \mathrm{Aa}$ & $7.04 \mathrm{Aa}$ & $3.97 \mathrm{Aa}$ & $3.44 \mathrm{Aa}$ & $2.78 \mathrm{Aa}$ & $2.17 \mathrm{Aa}$ & $1.80 \mathrm{Aa}$ \\
\hline \multirow[t]{2}{*}{$15-35$} & $69.19 \mathrm{Aa}$ & $26.49 \mathrm{Aa}$ & $4.75 \mathrm{Ba}$ & $2.20 \mathrm{Aa}$ & $2.40 \mathrm{Aa}$ & $1.70 \mathrm{Aa}$ & $1.82 \mathrm{Aa}$ & $1.65 \mathrm{Aa}$ \\
\hline & \multicolumn{8}{|c|}{ Planted pasture } \\
\hline $0-15$ & $58.57 \mathrm{Aa}$ & $25.99 \mathrm{Aa}$ & $8.52 \mathrm{Aa}$ & $2.90 \mathrm{Aa}$ & $4.29 \mathrm{Aa}$ & $2.74 \mathrm{Aa}$ & $2.69 \mathrm{Aa}$ & $1.76 \mathrm{Aa}$ \\
\hline $15-35$ & $48.29 \mathrm{Ba}$ & $32.93 \mathrm{Aa}$ & $11.09 \mathrm{Aa}$ & $5.32 \mathrm{Aa}$ & $4.17 \mathrm{Aa}$ & $3.31 \mathrm{Aa}$ & $2.74 \mathrm{Aa}$ & $2.13 \mathrm{Aa}$ \\
\hline \multirow[t]{3}{*}{$\mathrm{CV}(\%)^{(1)}$} & 18.60 & 17.08 & 31.26 & 45.71 & 32.37 & 34.74 & 32.05 & 21.89 \\
\hline & $0.15-0.106$ & $0.106-0.075$ & $0.075-0.053$ & $<0.053$ & & $\mathrm{MWD}^{(2)}$ & $\operatorname{GMD}^{(3)}$ & $\mathrm{SI}^{(4)}$ \\
\hline & \multicolumn{8}{|c|}{ Forest } \\
\hline $0-15$ & $1.29 \mathrm{Aa}$ & $1.50 \mathrm{Aa}$ & $1.21 \mathrm{Aa}$ & $1.38 \mathrm{Aa}$ & & $2.560 \mathrm{Aa}$ & $1.0060 \mathrm{Aa}$ & - \\
\hline \multirow[t]{2}{*}{$15-35$} & $1.75 \mathrm{Aa}$ & $1.42 \mathrm{Aa}$ & $1.25 \mathrm{Aa}$ & $1.46 \mathrm{Aa}$ & & $2.271 \mathrm{Aa}$ & $1.0038 \mathrm{Aa}$ & - \\
\hline & \multicolumn{8}{|c|}{ Traditional cropping system } \\
\hline $0-15$ & $1.88 \mathrm{Aa}$ & $1.47 \mathrm{Aa}$ & $1.10 \mathrm{Aa}$ & $1.22 \mathrm{Aa}$ & & $2.351 \mathrm{Aa}$ & $1.0039 \mathrm{Aa}$ & $0.937 \mathrm{Aa}$ \\
\hline \multirow[t]{2}{*}{$15-35$} & $1.26 \mathrm{Aa}$ & $1.18 \mathrm{Aa}$ & $1.02 \mathrm{Aa}$ & $1.42 \mathrm{Aa}$ & & $2.395 \mathrm{Aa}$ & $1.0047 \mathrm{Aa}$ & $1.064 \mathrm{Aa}$ \\
\hline & \multicolumn{8}{|c|}{ Capoeira } \\
\hline $0-15$ & $1.39 \mathrm{Aa}$ & $1.07 \mathrm{Aa}$ & $0.98 \mathrm{Aa}$ & $1.23 \mathrm{Aa}$ & & $2.506 \mathrm{Aa}$ & $1.0050 \mathrm{Aa}$ & 0.997Aa \\
\hline \multirow[t]{2}{*}{$15-35$} & $1.12 \mathrm{Aa}$ & $1.36 \mathrm{Aa}$ & $1.12 \mathrm{Aa}$ & $1.40 \mathrm{Aa}$ & & $2.628 \mathrm{Aa}$ & $1.0055 \mathrm{Aa}$ & $1.165 \mathrm{Aa}$ \\
\hline & \multicolumn{8}{|c|}{ Planted pasture } \\
\hline $0-15$ & $1.64 \mathrm{Aa}$ & $1.39 \mathrm{Aa}$ & $1.19 \mathrm{Aa}$ & $1.15 \mathrm{Aa}$ & & $2.478 \mathrm{Aa}$ & $1.0048 \mathrm{Aa}$ & 0.986Aa \\
\hline $15-35$ & $1.76 \mathrm{Aa}$ & $1.51 \mathrm{Aa}$ & $1.23 \mathrm{Aa}$ & $1.47 \mathrm{Aa}$ & & $2.309 \mathrm{Aa}$ & $1.0040 \mathrm{Aa}$ & $1.029 \mathrm{Aa}$ \\
\hline CV (\%) & 29.27 & 21.24 & 29.00 & 27.25 & & 8.96 & 0.14 & 14.14 \\
\hline
\end{tabular}

(1) CV: coefficient of variation; (2) MWD: mean weight diameter; (3) GMD: geometric mean diameter; (4) SI: sensitivity index. Uppercase letters compare types of management at the same depth. Lowercase letters compare depths within the same type of management. Mean values followed by the same letter do not differ by Tukey's test at 5\%.

The quantitative composition of the OM humified fractions was useful in discriminating the land use systems. Although the capoeira area had the highest TOC content and although the pasture area did not differ from the forest area for TOC content, chemical fractionation showed a tendency of $\mathrm{OM}$ on the surface to be less humified in the capoeira and pasture areas compared with the forest soil. The variation in $\mathrm{OM}$ humified fractions among the areas studied can be ascribed to differences in the input of fresh OMs. Assis et al. (2011) also assessed changes in land use by analyzing the OM lipid composition of an Lh under pasture, coffee, and native forests in Minas Gerais, southeastern Brazil. The authors found more important compounds for humification and stabilization of OM in soils under natural vegetation than in cultivated soils, and, in areas under forest and pasture, there was greater preservation of composts with depth, allowing inferences regarding the quality of organic matter between these land-use systems.

Humin was the most significant fraction for $\mathrm{C}$ storage in the soil. This fraction accounted for $41-44 \%$ of $\mathrm{OM}$ in the forest soil up to $65 \mathrm{~cm}$ deep. These results are similar to those reported by Marques (2009), who showed that between 12 and $54 \%$ of CT was in the humin fraction in the Lh in the South and Southeast of Brazil. Cunha et al. (2003) found values between 
Table 6. Carbon content of the fulvic acids (C-FA), humic acids (C-HA), and humin (C-H) fractions and humified carbon (humified-C) related to the TOC content in soils under different uses

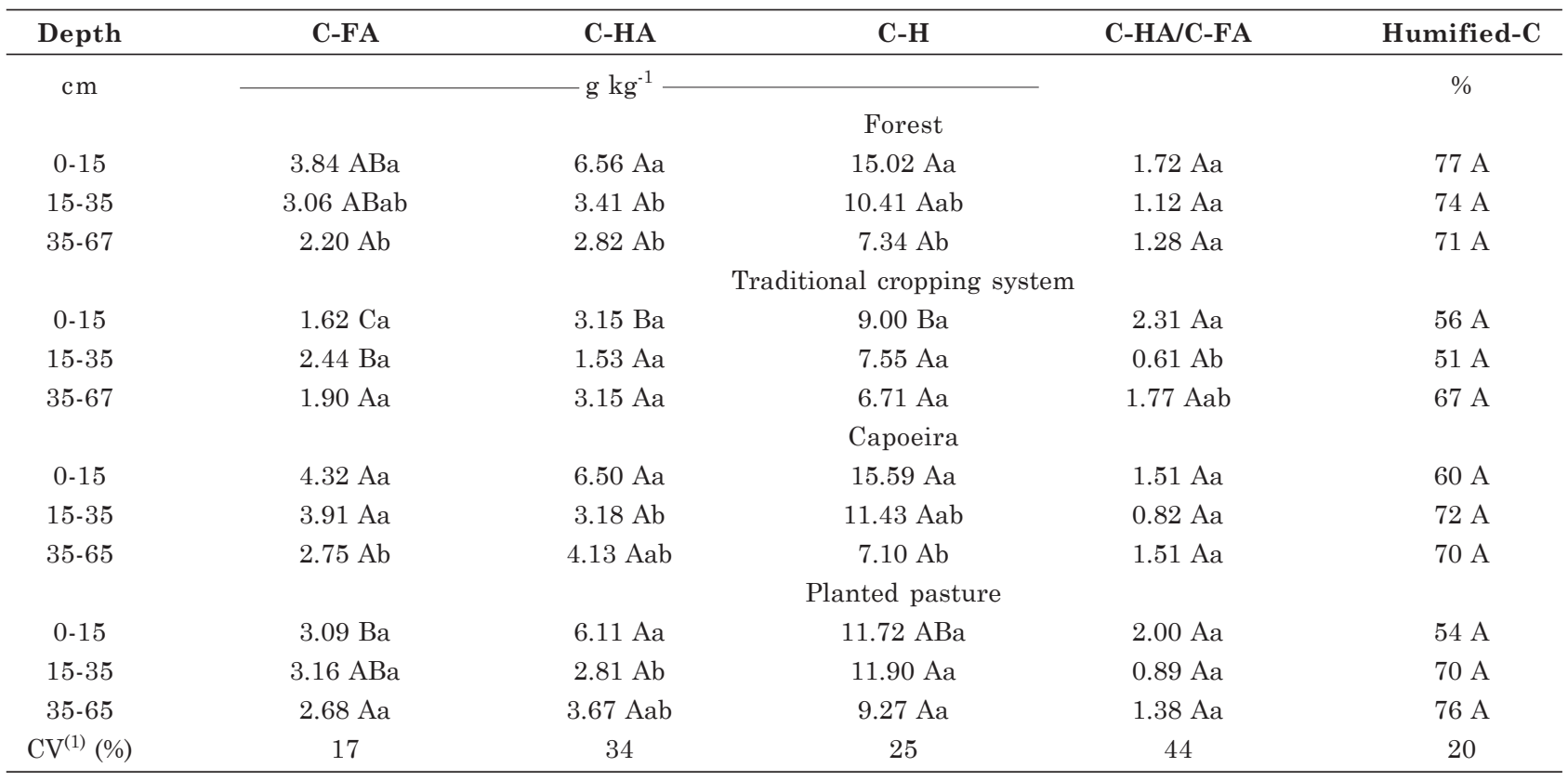

(1) CV: coefficient of variation. Uppercase letters compare types of management at the same depth. Lowercase letters compare depths within the same type of management. Mean values followed by the same letter do not differ by Tukey's test at $5 \%$.

47-65\% for this ratio in a cohesive Lh in the "Tabuleiros Costeiros". The predominance of humin is attributed to the physical and chemical stabilization of organic compounds with the mineral fraction (Stevenson, 1994) and is considered to be the most important fraction in terms of $\mathrm{C}$ sequestration.

Among the humified- $\mathrm{C}$ fractions, humic acid had the greatest relative changes in the cultivated soil, with a decrease of 52 and $55 \%$ in the $0-15$ and $15-35 \mathrm{~cm}$ layers, respectively, compared with the reference area. This corroborates the report of Canellas et al. (2004), who concluded that humic acids, as a fraction of humic substances, changes most with structural changes under cultivation.

The fulvic acid fraction exhibited the lowest quantities among the humified fractions. The C-FA content in the cultivated soil decreased $58 \%$ in relation to the forest soil in the surface layer.

In all the areas evaluated, values greater than 1.0 for the C-HA/C-FA ratio were observed, indicating a higher fraction of humic acids over fulvic acids, i.e., a higher condensation of humic compounds (Leite et al., 2003). According to Canellas et al. (2001), a C-HA/C-FA ratio close to 1.0 indicates a greater balance between the reactive humified fractions. The $\mathrm{OM}$ characterization of Oxisols in Viçosa in the Vale do Jequitinhonha regions of the state of Minas Gerais (mild climate) revealed the predominance of humic acids over fulvic acids in the surface layer (Longo, 1982).

The C-HA/C-FA ratio also remained high for the cultivated soil, showing that despite the significant reduction in the levels of humified-C, there were more evolved compounds. It is likely that cultivation favors the oxidation of fulvic acids (less evolved humic fractions) and the accumulation of more stable fractions and/or promotes the limitation of condensation reactions. Canellas et al. (2000) found that cultivation may promote an increase in humic acids, suggesting that the polycondensation of aromatic nuclei form fulvic acids that by condensing, give rise to humic acids.

\section{$\mathrm{BR}, \mathrm{MBC}$, and $q \mathrm{CO}_{2}$}

In general, all systems evaluated had low BR values (Table 7). The cultivated soil tended to show

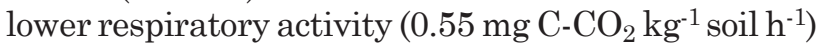
in the $0-5 \mathrm{~cm}$ layer, but did not differ significantly from the pasture and capoeira areas (which were also not different among themselves or in relation to the reference soil). These results agree with Assis (2008), who observed that the biological activity in pasture and capoeira soils was similar to forest soil and attributed this result to the large contribution of $\mathrm{OM}$ in the Lh studied. The low respiratory activity in the cultivated soil is most likely a result of the reduced microbial population, as indicated by the low MBC levels.

Interpretation of the results of biological activity, however, must be performed with caution because the decrease in $\mathrm{C}$ lost as $\mathrm{CO}_{2}$ through respiration may be indicative of a more efficient microbial biomass (Insam \& Domsch, 1988). However, an increased 
Table 7. Levels of $\mathrm{C}-\mathrm{CO}_{2}$ related to soil basal respiration (BR), microbial biomass $\mathrm{C}$ (MBC), and metabolic quotient $\left(q \mathrm{CO}_{2}\right)$ of soils under different uses

\begin{tabular}{|c|c|c|c|}
\hline Depth & BR & MBC & $q \mathrm{CO}_{2}$ \\
\hline $\mathrm{cm}$ & $\mathrm{mg} \mathrm{C}-\mathrm{CO}_{2} \mathrm{~kg}^{-1} \mathrm{~s} \mathrm{~h}^{-1}$ & $\begin{array}{l}\mathrm{mg} \mathrm{kg}^{-1} \\
\text { Forest }\end{array}$ & $\mathrm{mg} \mathrm{C}-\mathrm{CO}_{2} \mathrm{~g}^{-1} \mathrm{C}-\mathrm{MBC} \mathrm{h}^{-1}$ \\
\hline $0-5$ & $0.96 \mathrm{Aa}$ & $766.23 \mathrm{Aa}$ & $1.29 \mathrm{Ba}$ \\
\hline $5-10$ & $0.67 \mathrm{Ab}$ & $631.86 \mathrm{ABa}$ & $1.05 \mathrm{Aa}$ \\
\hline & & Traditional cropping system & \\
\hline $0-5$ & $0.55 \mathrm{Ba}$ & $181.92 \mathrm{Ba}$ & $5.81 \mathrm{Aa}$ \\
\hline $5-10$ & $0.51 \mathrm{Aa}$ & $\begin{array}{c}383.29 \mathrm{Ba} \\
\text { Capoeira }\end{array}$ & $1.41 \mathrm{Ab}$ \\
\hline $0-5$ & $0.68 \mathrm{Aba}$ & $536.25 \mathrm{Aa}$ & $2.03 \mathrm{ABa}$ \\
\hline $5-10$ & $0.64 \mathrm{Aa}$ & $\begin{array}{c}758.68 \text { Aa } \\
\text { Planted pasture }\end{array}$ & $0.85 \mathrm{Aa}$ \\
\hline $0-5$ & $0.78 \mathrm{Aba}$ & $701.81 \mathrm{Aa}$ & $1.17 \mathrm{Ba}$ \\
\hline $5-10$ & $0.50 \mathrm{Aa}$ & $591.69 \mathrm{ABa}$ & $0.88 \mathrm{Aa}$ \\
\hline $\mathrm{CV}^{(1)}(\%)$ & 21 & 28 & 114 \\
\hline
\end{tabular}

(1) CV: coefficient of variation. Uppercase letters compare types of management at the same depth. Lowercase letters compare depths within the same type of management. Mean values followed by the same letter do not differ by Tukey's test at $5 \%$.

respiration rate, as observed in the forest soil (0.96 mg C- $\mathrm{CO}_{2} \mathrm{~kg}^{-1}$ soil h${ }^{-1}$ ) in the 0-5 cm layer, can be interpreted as a desirable feature when it is considered that preserved soils have greater biological diversity, greater decomposition of organic waste, and greater availability of nutrients to plants. Assis (2008) reported that the production of accumulated $\mathrm{CO}_{2}$ increased with the addition of waste in the form of labile $\mathrm{C}$ in the $\mathrm{Lh}$ from the State of Minas Gerais. Assis Júnior et al. (2003) found higher BR values for native forest and pasture areas, and lower values for cultivated and deforested areas.

The MBC content in the forest soil was 766.23 and $631.86 \mathrm{mg} \mathrm{kg}^{-1}$ at $0-5$ and $5-10 \mathrm{~cm}$, respectively, which did not differ from the capoeira or pasture areas (Table 6). This can be attributed to the high OM levels found in these soils. Several studies have demonstrated a significant MBC loss in pasture and capoeira soils in relation to native vegetation soils (Milne \& Haynes, 2004; Xiao-gang et al., 2007; Lyyemperumal et al., 2007), thus reinforcing the relevance of OM for maintaining the quality of these soils.

Because the growth of microorganisms is limited by the availability of organic substrates, there was a reduction in the MBC levels in the cultivated area of 76 and $40 \%$ for the $0-5$ and $5-10 \mathrm{~cm}$ layers, respectively, compared with the forest area. Nsabimana et al. (2004) also found considerable inhibition of microbial biomass as a result of the succession from a primary forest to a cultivated area.

The MBC levels in the cultivated area decreased an average of 2.5 times more than the TOC and humified-C levels in the same area. These results demonstrate the sensitivity of MBC to changes in soil according to the land use system. Gama-Rodrigues
(1997) and Gama-Rodrigues et al. (2008) showed that microbial attributes are more effective than chemical attributes when measuring the dissimilarities between different types of vegetation covers.

Anderson \& Domsch (1993) proposed the utilization of the $q \mathrm{CO}_{2}$ to estimate the efficiency of substrate use by soil organisms. The $q \mathrm{CO}_{2}$ was lowest in forest and pasture soils, in agreement with Luna et al. (2008), who reported that the $q \mathrm{CO}_{2}$ decreases in more stable agroecosystems. These values were different compared with cultivated and capoeira soils; the $q \mathrm{CO}_{2}$ increased $350 \%$ in the cultivated area compared with the forest area. High $q \mathrm{CO}_{2}$ values reflect a high energy demand to maintain the microbial community and reflect the susceptibility of this system to C loss. These results corroborate other studies on highland soils in southern Brazil, which reported the highest $q \mathrm{CO}_{2}$ values in systems with greater human interference and the lowest values in the natural forest (Baretta et al., 2005).

\section{CONCLUSIONS}

1. Soil samples showed high TOC levels regardless of the type of land use.

2. Agricultural activity brought about changes in soil properties, especially chemical changes, with a significant reduction in organic constituents. The capoeira and pasture soils showed high organic carbon content but with a tendency of being less humified.

3. Humified-C was quantitatively found in the following order: $\mathrm{H}>\mathrm{HA}>\mathrm{FA}$. 


\section{LITERATURE CITED}

ANDERSON, T.H. \& DOMSCH, K.H. The metabolic quotient for $\mathrm{CO}_{2}\left(q \mathrm{CO}_{2}\right)$ as a specific activity parameter to assess the effects of environmental conditions, such as $\mathrm{pH}$, on the microbial biomass of forest soils. Soil Biol. Biochem., 25:393-395, 1993.

ANDRADE, F.V.; MENDONÇA, E.S.; ALVAREZ V., V.H. \& NOVAIS, R.F. Adição de ácidos orgânicos e húmicos em Latossolos e adsorção de fosfato. R. Bras. Ci. Solo, 27:10031011, 2003.

ANDRADE-LIMA, D. Esboço fitoecológico de alguns "brejos" de Pernambuco. Recife, Instituto de Pesquisas Agronômicas de Pernambuco, 1966. 7p. (Boletim Técnico, 8)

ARAÚJO FILHO, J.C.; BURGOS, N.; LOPES, O.F.; SILVA, F.H.B.; MEDEIROS, L.A.R.; MÉLO FILHO, H.F.R.; SILVA, F.B.R.; LEITE, A.P.; SANTOS, J.C.P.; SOUSA NETO, N.C.; SILVA, A.B.; LUZ, L.R.Q.P.; LIMA, P.C.; REIS, R.M.G. \& BARROS, A.H.C. Levantamento de reconhecimento de baixa e média intensidade dos solos do estado de Pernambuco. Recife, Embrapa Solos-UEP Recife/Rio de Janeiro, Embrapa Solos, 2000. 252p.

ASSIS, C.P. Matéria orgânica de Latossolos húmicos: Análises térmica e espectroscópica, efeito do uso e correção química. Viçosa, MG, Universidade Federal de Viçosa, 2008. 82p. (Tese de Doutorado)

ASSIS, C.P; GONZÁLEZ-VILA, F.J.; JUCKSCH, I.; GONZÁLEZ-PÉREZ, J.A.; NEVES, J.C.L.; LANI, J.L. \& MENDONÇA, E.S. Lipid abundance and composition of a humic Oxisol as a function of land use. Sci. Agric., 68:230236, 2011.

ASSIS, C.P.; JUCKSCH, I.; MENDONÇA, E.S.; NEVES, J.C.L.; SILVA, L.H.M. \& WENDLING, B. Distribution and quality of the organic matter in light and heavy fractions of a Red Latosol under different uses and management practices. Commun. Soil Sci. Plant Anal., 43:835-846, 2012.

ASSIS JÚNIOR, S.L.; ZANUNCIO, J.C.; KASUYA, M.C.M.; COUTO, L. \& MELIDO, R.C.N. Atividade microbiana do solo em sistemas agroflorestais, monoculturas, mata natural e área desmatada. R. Árvore, 27:35-41, 2003.

AZEVEDO, A.C. \& BONUMÁ, A.S. Partículas coloidais, dispersão e agregação em Latossolos. Ci. Rural, 34:609$617,2004$.

BARETTA, D.; SANTOS, J.C.P.; FIGUEIREDO, S.R. \& KLAUBERG FILHO, O. Efeito do monocultivo de Pinus e da queima do campo nativo em atributos biológicos do solo no planalto sul catarinense. R. Bras. Ci. Solo, 29:715$724,2005$.

BARTLETT, R.J. \& ROSS, S.D. Colorimetric determination of oxidizable carbon in acid soil solutions. Soil Sci. Soc. Am. J., 52:1191-1192, 1988.

BOLINDER, M.A.; ANGERS, D.A.; GREGORICH, E.G. \& CARTER, M.R. The response of soil quality indicators to conservation management. Can. J. Soil Sci., 79:37-45, 1999.
BRASIL. Ministério da Agricultura. Departamento Nacional de Pesquisa Agropecuária. Divisão de Pesquisa Pedológica. Levantamento exploratório-reconhecimento de solos do Estado de Pernambuco. Recife, 1972. 2v. (DNPEA. Boletim Técnico, 28; SUDENE. Série Pedológica, 16)

BRUNETTO, G.; COMIN, J.J.; SCHMITT, D.E.; GUARDINI, R.; MEZZARI, C.P.; OLIVEIRA, B.S.; MORAES, M.P.; GATIBONI, L.C.; LOVATO, P.E. \& CERETTA, C.A. Changes in soil acidity and organic carbon in a sandy typic Hapludalf after medium-term pig-slurry and deeplitter application. R. Bras. Ci. Solo, 36:1620-1628, 2012.

CAMARGO, F.O.A.; GIANELLO, C.; TEDESCO, M.J. \& VIDOR, C. Nitrogênio orgânico do solo. In: SANTOS, G.A. \& CAMARGO, F.A.O., ed. Fundamentos da matéria orgânica do solo: Ecossistemas tropicais e subtropicais. Porto Alegre, Gênesis, 1999. p.117-138.

CANELLAS, L.P.; BERNER, P.G.; SILVA, S.G.; SILVA, M.B. \& SANTOS, G.A. Frações da matéria orgânica em seis solos de uma topossequência no Estado do Rio de Janeiro. Pesq. Agropec. Bras., 35:133-143, 2000.

CANELLAS, L.P.; ESPINDOLA, J.A.A.; REZENDE, C.E.; CAMARGO, P.B.; ZANDONADI, D.B.; RUMJANEK, V.M.; GUERRA, J.G.M.; TEIXEIRA, M.G. \& BRAZ-FILHO, R. Organic matter quality in a soil cultivated with perennial herbaceous legumes. Sci. Agric., 61:53-61, 2004.

CANELLAS, L.P.; SANTOS, G.A.; RUMJANEK, V.M.; MORAES, A.A. \& GURIDI, F. Distribuição da matéria orgânica e características de ácidos húmicos em solos com adição de resíduos de origem urbana. Pesq. Agropec. Bras., 36:1529-1538, 2001.

CARVALHO, D.M. \& SOUZA, J.P. Análise da cadeia produtiva da caprino-ovinocultura em Garanhuns. In: CONGRESSO DA SOCIEDADE BRASILEIRA DE ECONOMIA, ADMINISTRAÇÃO E SOCIOLOGIA RURAL, 2008, Rio Branco. Anais... Rio Branco, Sociedade Brasileira de Economia, Administração e Sociologia Rural, 2008. p.45-72.

CASTRO FILHO, C. Effects of liming on characteristics of a Brazilian Oxisol at three levels of organic matter as related to erosion. Columbus, The Ohio State University, 1988. (Tese de Doutorado)

CASTRO FILHO, C.; LOURENÇO, A.; GUIMARÃES, M.F. \& FONSECA, I.C.B. Aggregate stability under different soil management systems in a Red Latosol in the state of Paraná, Brazil. Soil Till. Res., 65:45-51, 2002.

CERETTA, C.A.; DURIGON, R.; BASSO, C.J.; BARCELLOS, L.A.R. \& VIEIRA, F.C.B. Características químicas de solo sob aplicação de esterco líquido de suínos em pastagem natural. Pesq. Agropec. Bras., 38:729-735, 2003.

CUNHA, T.J.F.; RIBEIRO, L.P.; SILVA, E.F. \& CONCEIÇÃO, M. Caracterização e natureza do húmus de Latossolos Amarelos coesos de tabuleiros na região do recôncavo baiano. Magistra, 15:147-154, 2003.

DON, A.; SCHUMACHER, J. \& FREIBAUER, A. Impact of tropical land-use change on soil organic carbon stocks - a meta-analysis. Global Change Biol., 17:1658-1670, 2011. 
EMPRESA BRASILEIRA DE PESQUISA AGROPECUÁRIA EMBRAPA. Centro Nacional de Pesquisa de Solos. Manual de métodos de análise de solo. 2.ed. Rio de Janeiro, 1997. 212p.

EMPRESA BRASILEIRA DE PESQUISA AGROPECUÁRIA EMBRAPA. Centro Nacional de Pesquisa de Solos. Levantamento de reconhecimento de baixa e média intensidade dos solos do estado de Pernambuco. Rio de Janeiro, 2000. 381p. (Boletim de Pesquisa, 11)

EMPRESA BRASILEIRA DE PESQUISA AGROPECUÁRIA EMBRAPA. Centro Nacional de Pesquisa de Solos. Sistema brasileiro de classificação de solos. 3.ed. Brasília, 2013. 353p.

GALVÃO, C.V. Contribuição ao estudo da ecodinâmica do semi-árido nordestino: áreas do Agreste ocupadas por pecuária e algarobeira. R. Iniciação Ci. FFC, 7:22-33, 2007.

GAMA-RODRIGUES, A.C. Ciclagem de nutrientes por espécies florestais em povoamentos puros e mistos em solos de tabuleiro da Bahia, Brasil. Viçosa, MG, Universidade Federal de Viçosa, 1997. 107p. (Tese de Doutorado)

GAMA-RODRIGUES, E.F.; GAMA-RODRIGUES, A.C.; PAULINO, G.M. \& FRANCO, A.A. Atributos químicos e microbianos de solos sob diferentes coberturas vegetais no Norte do Estado do Rio de Janeiro. R. Bras. Ci. Solo, 32:1521-1530, 2008.

GOL, C. The effects of land use change on soil properties and organic carbon at Dagdami river catchment in Turkey. J. Environ. Biol., 30:825-830, 2009.

GUPPY, C.N.; MENZIES, N.W.; MOODY, P.W. \& BLAMEY, F.P.C. Competitive sorption reactions between phosphorus and organic matter in soil: A review. Aust. J. Soil Res., 43:189-202, 2005.

HAYNES, R.J. \& WILLIAMS, P.H. Changes in soil solution composition and $\mathrm{pH}$ in urine-affected areas of pasture. J. Soil Sci., 43:323-334, 1992.

HAYNES, R.J. \& WILLIAMS, P.H. Nutrient cycling and soil fertility in the grazed pasture ecosystem. Adv. Agron., 49:119-199, 1993.

HUE, N.V. \& LICUDINE, D.L. Amelioration of subsoil acidity through surface application of organic manures. J. Environ. Qual., 28:623-632, 1999.

INSAM, H. \& DOMSCH, K.H. Relationship between soil organic carbon and microbial biomass on chronosequences of reelamation sites. Microbiol. Ecol., 15:177-188, 1988.

KEMPER, W.D. \& CHEPIL, W.S. Size distribution of aggregates. In: BLACK, C.A., ed. Methods of soil analysis. Madison, American Society of Agronomy, 1965. p.449-510.

KEMPER, W.D. \& ROSENAU, R.C. Aggregate stability and size distribution. In: KLUTE, A., ed. Methods of soil analysis. Madison, American Society of Agronomy, 1986. p.425-442.

KER, J.C. Latossolos do Brasil: Uma revisão. Geonomos, 5:1740, 1997.
LAMEPE/ITEP. Informações climáticas do Estado de Pernambuco. Available at: <http://www.itep.br/ itep_lamepe/site/tela3.php>. Accessed: Jan. 28, 2010.

LEITE, L.F.C.; MENDONÇA, E.S.; NEVES, J.C.L.; MACHADO, P.L.O.A. \& GALVÃO, J.C.C. Estoques totais de carbono orgânico e seus compartimentos em Argissolo sob floresta e sob milho cultivado com adubação orgânica e mineral. R. Bras. Ci. Solo, 27:821-832, 2003.

LEPSCH, I.F. \& BUOL, S.W. Oxisol-landscape relationship in Brazil. In: INTERNATIONAL SOIL CLASSIFICATION WORKSHOP, 13., Campinas, 1986. Proceedings... Campinas, SNLCS/EMBRAPA/University of Puerto Rico, 1986. p.174-189.

LONGO, J.V. Fracionamento e caracterização de substâncias húmicas em materiais de solos. Viçosa, MG, Universidade Federal de Viçosa, 1982. 66p. (Dissertação de Mestrado)

LUNA, R.G.; COUTINHO, H.D.M. \& GRISI, B.M. Evaluation of pasture soil productivity in the semi-arid zone of Brazil by microbial analyses. Braz. J. Microbiol., 39:409-413, 2008.

LYYEMPERUMAL, K.; ISRAEL, D.W. \& SHI, W. Soil microbial biomass, activity and potential nitrogen mineralization in a pasture: Impact of stock camping activity. Soil Biol. Biochem., 39:149-157, 2007.

MARIN-SPIOTTA, E.; SWANSTON, C.W.; TORN, M.S.; SILVER, W.L. \& BURTON, S.D. Chemical and mineral control of soil carbon turnover in abandoned tropical pastures. Geoderma, 143:49-62, 2008.

MARQUES, F.A. Matéria orgânica de Latossolos com horizonte A húmico. Piracicaba, Escola Superior de Agricultura Luiz de Queiroz, 2009. 143p. (Tese de Doutorado)

MARQUES, F.A.; CALEGARI, M.R.; VIDAL-TORRADO, P. \& BUURMAN, P. Relationship between soil oxidizable carbon and physical, chemical and mineralogical properties of Umbric Ferralsols. R. Bras. Ci Solo, 35:2540, 2011.

MELO, J.I.M. \& RODAL, M.J.N. Levantamento florístico de um trecho de floresta serrana no planalto de Garanhuns, Estado de Pernambuco. Acta Sci. Biol. Sci., 25:173-178, 2003.

MENDONÇA, E.S. \& MATOS, E.S. Matéria orgânica do solo: métodos de análises. Viçosa, MG, Universidade Federal de Viçosa, 2005. 77p.

MIELNICZUK, J.; BAYER, C.; BESAN, F.M.; LOVATO, T.; FERNÁNDEZ, F.F. \& DEBARBA, L. Manejo de solo e culturas e sua relação com os estoques de carbono e nitrogênio do solo. In: CURI, N.; MARQUES, J.J. \& ALVAREZ V., V.H., eds. Tópicos em ciência do solo. Viçosa, MG, Sociedade Brasileira de Ciência do Solo, 2003. v.3, p.209-248.

MILNE, R. \& HAYNES, R. Soil organic matter, microbial properties, and aggregate stability under annual and perennial pastures. Biol. Fert. Soils, 39:172-178, 2004.

MIYAZAWA, M.; PAVAN, M.A. \& CALEGARI, A. Efeito de material vegetal na acidez do solo. R. Bras. Ci. Solo, 17:411416, 1993.

NARAMABUYE, F.X. \& HAYNES, R.J. Short-term effects of three animal manures on soil $\mathrm{pH}$ and $\mathrm{Al}$ solubility. Aust. J. Soil Res., 44:515-521, 2006. 
NOLLA, A. \& ANGHINONI, I. Atividade e especiação química na solução afetadas pela adição de fósforo em Latossolo sob plantio direto em diferentes condições de acidez. R. Bras. Ci. Solo, 30:955-963, 2006.

NSABIMANA, D.; HAYNES, R.J. \& WALLIS, F.M. Size, activity and catabolic diversity of the soil microbial biomass as affected by land use. Appl. Soil Ecol., 26:81-92, 2004.

ODUM, E.P. Ecologia. Rio de Janeiro, Guanabara, 1985. 434p.

PINHEIRO, E.F.M.; PEREIRA, M.G. \& ANJOS, L.H.C. Aggregate distribution and soil organic matter under different tillage systems for vegetable crops in a Red Latosol from Brazil. Soil Till. Res., 77:79-84, 2004.

QUEIROZ NETO, J.P. \& CASTRO, S.S. Formações superficiais e Latossolos Vermelho-Amarelo húmico na área de Bragança Paulista, Estado de São Paulo, Brasil. In: CONGRESSO BRASILEIRO DE GEOLOGIA, 18., Porto Alegre, 1974. Anais... Porto Alegre, Sociedade Brasileira de Geologia, 1974. p.65-83.

RUKSHANA, F.; BUTTERLY, C.R.; BALDOCK, J.A. \& TANG, C. Model organic compounds differ in their effects on $\mathrm{pH}$ changes of two soils differing in initial pH. Biol. Fert. Soils, 47:51-62, 2011.

SAS Institute. Sas user's guide: statistics. Version 9.1, Cary, 2006.

SHAND, C.A. \& COUTTS, G. The effects of sheep faeces on soil solution composition. Plant Soil, 285:135-148, 2006.

SILVA, A.C. Dinâmica da cobertura pedológica de uma área cratônica do Sul de Minas Gerais. Piracicaba, Escola Superior de Agricultura Luiz de Queiroz, 1997. 191p. (Tese de Doutorado)

SILVA, A.C. \& VIDAL-TORRADO, P. Gênese dos Latossolos Húmicos e sua relação com a evolução da paisagem numa área cratônica do sul de Minas Gerais. R. Bras. Ci. Solo, 23:329-341, 1999 .
SILVA, A.C.; VIDAL-TORRADO, P.; GONZÁLEZ-PEREZ, M.; MARTIN NETO, L. \& VASQUES, F.M. Relações entre matéria orgânica do solo e declividade de vertentes em toposseqüencia de Latossolos do sul de Minas Gerais. R. Bras. Ci. Solo, 31:1059-1068, 2007.

SILVA, J.A.A. \& SILVA, I.P. Estatística experimental aplicada à ciência florestal. Recife, Universidade Federal Rural de Pernambuco, 1982. 292p.

SIX, J.; CONANT, R.T.; PAUL, E.A. \& PAUSTIAN, K. Stabilization mechanisms of soil organic matter: Implications for C-saturation of soils. Plant Soil, 241:155$176,2002$.

STEVENSON, F.J. Humus chemistry: Genesis, composition, and reactions. 2.ed. New York, John Wiley \& Sons, 1994. 496p.

TABARELLI, M. \& SANTOS, A.M.M. Uma breve descrição sobre a história natural dos Brejos Nordestinos. In: PORTO, K.C.; CABRAL, J..J.P. \& TABARELLI, M., eds. Brejos de Altitude em Pernambuco e Paraíba-história natural, ecologia e conservação. Brasília, Ministério do Meio Ambiente, 2004. p.227-284.

VACCARI, F.P.; LUGATO, E.; GIOLI, B.; D'ACQUI, L.; GENESIO, L.; TOSCANO, P.; MATESE, A. \& MIGLIETTA, F. Land use change and soil organic carbon dynamics in Mediterranean agro-ecosystems: The case study of Pianosa Island. Geoderma, 175:29-36, 2012.

VELLOSO, A.L.; SAMPAIO, E.V.S.B. \& PAREYN, F.G.C. Ecorregiões propostas para o bioma Caatinga. Recife, Associação Plantas do Nordeste, Instituto de Conservação Ambiental e The Nature Conservancy do Brasil, 2002. 76p.

XIAO-GANG, L.; LI, F.; BHUPINDERPAL-SINGH, R.; ZED, Z. \& ZHENG-YAN, Z. Soil management changes organic carbon pools in alpine pastureland soils. Soil Till. Res., 93:186-196, 2007.

YEOMANS, J.C. \& BREMNER, J.M. A rapid and precise method for routine determination of organic carbon in soil. Commun. Soil Sci. Plant Anal., 19:1467-1476, 1988. 